\title{
REVIEW OF AQUACULTURAL PRODUCTION SYSTEM MODELS
}

\author{
C. C. Anyadike ${ }^{1}$, C. C. Mbajiorgu ${ }^{2}$ and G. N Ajah ${ }^{3}$

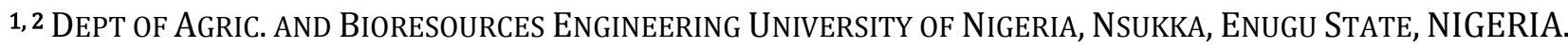 \\ 3 Department of Electrical EngineEring University of Nigeria, NSUKKA, ENUGU STATE, NiGERIA. \\ E-mail addresses: ${ }^{1}$ chinenye.anyadike@unn.edu.ng, 2 constantine.majiorgu@unn.edu.ng, \\ 3genesis.ajah.pg62628@unn.edu.ng
}

\begin{abstract}
The success and profitability of aquaculture production is highly dependent on the proper management employed during the culture period. This management is synonymous with water management since water of suitable quality and quantity is a pre-requisite for any successful aquacultural production. The knowledge of the environment (water) enhances better management. However, the complexity of an aquaculture system which result from multiple interactions makes it difficult to predict how the aquatic community will respond to changes with simple methods of analysis, especially if the methods address a single stressor at a time. These necessitated the development of numerous aquatic ecosystem models such as the Fish Simulation Culture Model (FIS-C), Tilapia Farming Support Tool (TFST), Farm Aquaculture Resource Management (FARM), Pond-Water Availability Period (PWAP) model, AquaFarm and Raceway design and simulation system (RDSS)), which have been used for years as tools to interpret, predict and better understand water quality changes. This paper reviewed existing simulation models of aquacultural production systems with the aim of adopting a suitable one for predicting the environment, performance of African cultured indigenous fish species under different management scenarioes. The reviewed models were found to have addressed specific problem that pertain to some foreign species, production systems and locality. There was none that could be used to model the effects of different management scenario and their effects on African Catfish (Clarials gariepinus) cultured in intensive static aquacultural system. Hence, the problem of predicting the environmental condition, so as to determine point of diminishing returns and optimize yield in an economical way still remains elusive for most fish farms in Nigeria. There is therefore a serious need to develop models that can predict the effects of environment on the performance of indigenous fish species. This will aid stake holders in predicting different management scenario so as to achieve a better crop (fish) yield.
\end{abstract}

Keywords: Aquaculture, Management, Models, Sustainability, Review

\section{INTRODUCTION}

The objective of intensive aquaculture practice has been to increase profitability by maximizing harvest weight (biomass) per unit volume/area of production system. However, these practices almost always exceed the biological carrying capacity of the production unit, since the cultured fish depend on their environment (water) for the supply of resources (food, oxygen), removal of metabolic wastes (ammonia, carbon dioxide, feces, urine) and for maintenance of conditions (temperature, $\mathrm{pH}$, salinity, etc.) suitable for growth, survival and reproduction [1].As with livestock production, overcrowding usually leads to problems with environmental degradation, disease, off-flavor (aquatic animals), and a reduction in individual performance of the cultured species[2, 3]. This affects the profitability and sustainability of the farm. Sustainability is a major challenge in aquaculture development, as a sustainable aquaculture system that does not provide a suitable standard of living for the producer will not last long and likewise a highly profitable aquaculture system that heavily exploits and degrades the natural resources and the environment will also have a limited lifespan [4]. An acceptable balance between a profitable and sustainable venture [5] is important in ensuring the growth and development of aquaculture. Successful aquaculture production is therefore, highly dependent on the proper management employed during the culture period. Management in aquaculture

${ }^{*}$ Corresponding author, Tel: +234-803-874-1426 
is synonymous with water management since water of suitable quality and quantity is a pre-requisite for any successful aquacultural production. Hence an adequate knowledge of the ecosystem processes and interactions is vital in managing water quality and reducing environmental degradation of intensive fish production systems. Aquacultural systems as production aquatic ecosystems are highly complex. This is because of the biological variability that is added to the physical and chemical processes that also operate in the systems [1]. The outcome of these complex interactions is made more difficult to interpret by the different indices that are used to report metabolic rate: oxygen consumption, respiration (carbon dioxide production), ammonia excretion, feed consumption, fish growth, and feed conversion [6].

Managing the environment of the cultured fish and the effluents therefore require an understanding of the complex interactions and processes that occur in the system. Numerous experiments are mostly required to investigate all the important factors and their interactions. This demand a lot of research time, facilities and resources. Furthermore, the study of interactions between components is seldom feasible to experiment on in their natural environment. This has led to incomplete and expensive experiments, lack of useful result and understanding of the system especially in Nigeria. Modelling can be used to facilitate the evaluation of these complex interactions and aid understanding of the processes and dynamics of the system. It can also be used to predict instant condition of a system, its effects on the cultured crop and the environmental impact. Simulation models therefore, offer great potentials for the study and design of agricultural/aquacultural production systems and for education and training. They are known to facilitate complex studies and evaluation of the complex- interactions, providing working tool for conducting numerous experiments on time. They are used to evaluate the consequences of various hypotheses or management-strategies, making intelligent predictions which facilitate the day -to- day management of aquacultural operations (determining stocking and feeding rates, predicting dissolved oxygen levels and examining the effects of different management strategies)[7]. This paper therefore reviewed simulation models of aquaculture production systems, with a view of adopting a suitable model for predicting the environment, performance and economic viability of African Catfish cultured in tank-based systems.

\section{MODELING AQUACULTURAL PRODUCTION SYSTEMS}

The environment of aquatic organism is water as earlier stated, however, once the water is used for culture, its quality deteriorates. In natural aquatic ecosystem unlike the production system, the fishes are not densely stocked; they spread throughout the entire aquatic environment. The waste generated is minimal due to large quantities of water which results in unlimited dilution of the waste and self-purification processes, and the fishes move from areas of high to low waste concentration. However, in a typical aquaculture production system, the fishes are densely populated in a restricted environment; natural attributes such as waste dilution and self-purification are minimized resulting in a high build-up of waste which progressively affects the water quality. This deterioration of environmental conditions is ultimately traceable to the use of feed. Feed input is strongly correlated with deterioration of water quality in ponds [8]. In general, as feed input increases, more fish metabolic waste enters the pond, phytoplankton density, concentration of total ammonia and carbon dioxide increase, and the concentration of dissolved oxygen at dawn decreases [9]. The poor water quality cause stress in fish resulting in reduced fish growth rates, poor feed conversion, and reduced resistance to disease. In extreme instances, such as depletion of dissolved oxygen, fish may be unable to adapt and will die [10]. Hence, water quality models are paramount in discussing aquatic ecosystems.

Numerous water quality models have been developed for specific purposes. Some of these model and their descriptions are presented in[11].However, to enhance the understanding of aquaculture production systems some functional scheme has been used in classifying aquacultural models. These according to [12-13] include biological, engineering, bioeconomic or economic, growth, pond ecosystem, production and survival models, and environmental models, these are described as follows:

- Biological models: These are concerned with modeling the responses (growth, survival, reproduction) and interactions (eating, breathing, and excretion) of the cultured fish and its environment.

- Engineering models: They are concerned with designing, managing and controlling the

Vol. 35, No. 2, April 2016 
environment of the fish. These models use biological models to determine which type of environment is required.

- Bioeconomic or economic models are concerned with the economic feasibility of aquaculture enterprises: the costs associated with providing and maintaining the culture environment and the revenues from expected production. These models tie together the biological and engineering models and use them to define the production function as a basis for economic analysis. Costs are assigned to all inputs while prices are assigned to all outputs or products. From these basic elements various types of economic analysis are conducted.

- Growth Models, growth in fish is governed by a variety of environmental factors including temperature, oxygen concentration, unionized ammonia, food availability, salinity and photoperiod. In addition, fish growth is influenced by one or more internal factors including body size and genotype. The combined effect of all or a number of these factors can range from complete growth inhibition to maximum growth.

- Pond Ecosystem Models: They attempt to incorporate the many components and processes relevant to the pond environment. These include the biotic components (cultured organisms, phytoplankton, zooplankton, benthic organisms, bacteria-detritus complex), the abiotic components (water characteristics, such as $\mathrm{pH}$, alkalinity, carbon dioxide, temperature, dissolved oxygen, ammonia-ammonium, nitrite, nitrate, phosphorous, organic matter; soil type; climatic factors such as solar radiation, wind, evaporation and precipitation) and management factors (anthropogenic activities such as sediment, nutrients and fertilizers from surrounding watersheds). The core of a pond model is usually some type of growth model, linked to this are the environmental factors that are considered important or of interest for the particular problem under study, and the management factors (especially inputs like feeds and fertilizers).

- Production Models: Aquaculture production is predicated on the survival and growth of the cultured organisms. Thus, production is easily modeled as the sum of the weights of each surviving fish or the product of the average

Nigerian Journal of Technology weight of the fish and the number of fish. Production is measured as total weight or biomass of the fish. The size distribution of the fish at harvest is important to determine the number of fish that reach market size.

- Survival Models: Most survival models merely assume an expected value for survival at the end of the culture period based on past experience. A linear or curvilinear equation is then fitted to the value to determine survival at any time during culture.

- Environmental models: They can be thought of as simulations of reality incorporating knowledge and experience to simplify complex situations, and simulate complicated operations or situations that may be difficult or unsafe (worst case scenario modelling) to manipulate in the natural environment $[4,14,15]$. Environmental modelling has become increasingly popular in the sciences in recent years [16].Environmental models are also used in aquaculture for farm management to simulate the quality of the water within the farming system to help minimise fish deaths and predict profitability [17]. A common method used for basic modelling is called the Mass Balance equation this can be utilised for many different parameters but is most widely used in a water quality context to model nitrogen and phosphorus concentrations in and from aquaculture systems.

\section{SIMULATION MODELS FOR AQUACULTURAL SYSTEMS}

Model development effort have been undertaken by various researchers to identify and quantify the cause, effect and relationships between water quality parameters, the physical environment and aquatic ecosystem in production ponds, tanks and other stagnant water bodies, as well as prediction of general pond dynamics. A brief summary of some of these computer simulation models for aquaculture production systems are as follow.

a. Fish Simulation Culture Model (FIS-C): A generic bioenergetics model for Chinook salmon was modified to estimate solid wastes from a commercial net-pen aquaculture operation in a Minnesota mine-pit lake. This bioenergetics based model was used for aquacultural waste load application and it is developed by [18]. FIS-C offers substantial benefits to users for assessing aquacultural waste loads. It can provide rapid,

Vol. 35, No. 2, April 2016 
short and long term estimates of consumption and sediment solids without the necessity of performing multiple, user intensive simulations. Scenarios may be created that allow for the assessment of various management strategies of an aquaculture facility to meet environmental or regulatory requirements, prior to costly implementation. Also, FIS-C provides the aquaculture manager with a means of estimating food consumption and ration wastage for fish stocks of changing size and with changing temperatures. Potentially, FIS-C may provide estimates of $\mathrm{N}$ loading and oxygen demand for an aquaculture operation as well. However, the model is currently extremely sensitive to the assumption of an aquacultural operation predicated on maximal stock growth. Because optimal economic and/or environmental management strategies and management for maximal stock growth do not necessarily coincide, FIS-C may not currently be a precise predictor of extant conditions. However, it will provide an estimate of the maximal loading for a given stock level, and may provide insights into the 'cost' of management or environmental decisions in the reduction of stock growth from maximal levels.

b. Tilapia Farming Support Tool (TFST): is an economic tool developed by Nefisco and Xi [19]. This economic model assists you in the formulation of the most optimal Tilapia farming systems taking into consideration the local economy and consumer preferences. The program is based on population dynamics. In other words, it follows each individual fish in your virtual pond throughout the rearing period. In this respect, it differs from other Aquacultural Simulation software, which is based mostly on the flow of nutrients into the ponds. The program does not incorporate natural productivity or the water quality of your pond.

c. Farm Aquaculture Resource Management (FARM):This is a model for assessment of coastal and offshore shellfish aquaculture at the farmscale developed by [20]. The modeling framework applies a combination of physical and biogeochemical models, bivalve growth models and screening models for determining shellfish production and for eutrophication assessment. FARM currently simulates the above interrelations for five bivalve species: the Pacific oyster Crassostrea gigas, the blue mussel Mytilus edulis, the Manila clam Tapes phillipinarum, the cockle Cerastoderma edule and the Chinese scallop Chlamys farreri. Shellfish species combinations (i.e. polyculture) may also be modeled. The Farm Aquaculture Resource Management (FARM) model is directed both at the farmer and the regulator, and has three main uses: (i) prospective analyses of culture location and species selection; (ii) ecological and economic optimisation of culture practice, such as timing and sizes for seeding and harvesting, densities and spatial distributions (iii) environmental assessment of farm-related eutrophication effects (including mitigation).

d. Pond-Water Availability Period (PWAP) model: developed by [21] is a simulation model that expresses water budget for fish ponds based on prevailing climatic and hydrological conditions. The model captures the key physical elements of the hydrological system influencing the water budget of the pond, but at a level of complexity that is consistent with data limitations encountered in many developing countries. This simulation model calculates variations in pondwater depth due to the physical processes by starting with the basic climatic water balance involving water gain into the pond from direct rainfall and loss from the pond-water surface through evaporation, and then including potential inflow from surface water runoff from the immediate surroundings of the pond, deep percolation and lateral seepage or inflow. The PWAP model was developed for regional-scale assessment of pond-water availability as a key determinant of pond aquaculture development potential. The model can be used in an exploratory manner to construct scenarios that help identify possibilities for prolonging pond water availability duration in these areas by enhancing water harvesting and storage under different climatic and topographical conditions. Initially developed for point-based evaluation, the model is being further programmed for evaluation in a GIS environment to generate gridded maps of pondwater availability.

e. AQUAFARM: This is a simulation and decision support software product for the design and management planning of finfish and crustacean aquaculture facilities[22]. AquaFarm is primarily based on mechanistic principles, with empirical components added as necessary to support

Vol. 35, No. 2, April 2016

451

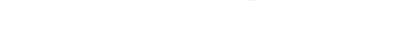


practically oriented design and management analyses for a wide range of users. AquaFarm was developed to support a wide range of extensive and intensive, fishery-supplementation and foodfish aquaculture facilities, and a wide range of user perspectives (e.g. educators, developers, and producers), within a single software application. AquaFarm is a stand-alone computer application, programmed in Borland $\mathrm{C}++$ and requiring a $\mathrm{PC}-$ based Microsoft Windows $\AA$ operating environment. It provides: (1) simulation of physical, chemical, and biological unit processes; (2) simulation of facility and fish culture management; (3) compilation of facility resource and enterprise budgets; and (4) a graphical user interface and data management capabilities. These analytical tools are combined into an interactive, decision support system for the simulation, analysis, and evaluation of alternative design and management strategies. Based on these given specifications, aquaculture facilities are simulated, resource requirements and enterprise budgets compiled, and operation and management schedules determined so that fish production objectives are achieved. Facility performance is reported to the user as management schedules, summary reports, enterprise budgets, and tabular and graphical compilations of time-series data for unit process, fish, and water quality variables. Application of AquaFarm to various types of aquaculture systems has been demonstrated [22]. AquaFarm is applicable to a range of aquaculture interests, including education, development, and production.

f. Raceway design and simulation system (RDSS): An event-based program to simulate the day-today operations of multiple-tank raceways. A systems approach to the simulation of a raceway facility was used to develop RDSS, written in Visual Basic for Applications and run within Microsoft1 Office Excel 2003 [23]. The software allows users to manage their raceways more efficiently by providing a tool to simulate the operation of an existing raceway or to predict conditions in a raceway under a wide variety of operating conditions. The program simulates the conditions in a system of multiple tanks that may be arranged in sets of parallel raceways with serial water flow. The user may specify the use of overflow weirs or customized oxygen injection points in order to re-oxygenate the water flow from succeeding tanks in each raceway. During the course of the simulation, the user may specify the size, number, location, and price of any new fish introduced into any raceway tank. Subsequent movement of fish between tanks or removal of part or all of a cohort is tracked by the program. Input data required include properties of the influent water such as temperature, flowrate, dissolved oxygen, $\mathrm{pH}$, total ammonia nitrogen, and salinity. Fish growth is predicted using these input data and stocking information that is provided by the user. Fish mortality may be specified for each tank in a raceway. In addition, the costs of food, the purchase cost of fish, and the revenue from the sale of fish are also tracked. RDSS does not take into account some important economic factors that affect the overall profitability of a raceway system such as utility and operating labor costs and investment costs. However, RDSS can benefit producers evaluating the production potential of a new site, educators and extension agents teaching aquaculture concepts, and researchers investigating the effects of alternative economic and biophysical factors on aquaculture management.

g. A bioenergetics growth model for Nile tilapia (Oreochromis niloticus)based on limiting nutrients and fish standing crop in fertilized ponds [24]: this model was written using a dynamic modeling language called STELLA® II [25] and was based on a model developed by [26]. The model used a time step of one day, and the equations were solved using a 4th-order RungeKutta numerical integration method. In this model, the growth of Nile tilapia in fertilized ponds has been linked directly to limiting nutrients and fish standing crop which are the bases for the estimation of naturally available foods. The model indicates that growth variations in ponds receiving the same nitrogen and phosphorus inputs were caused by carbon limiting primary production. Model results will improve our understanding of aquaculture pond ecosystems and will be useful for the optimization of fertilizer utilization.

h. Other aquaculture models: There are other models that represent different interactions in aquacultural systems rather than the whole system itself. For example, [27] constructed a mathematical model for a fish breeding pond for carp, silver carp and bighead. The model is a 
system of ordinary differential equations describing the material transformations in the pond ecosystem. It allows a choice of optimal regimes of the aeration, feeding and fertilization of a pond for different climatic conditions in order to maximize the yield. Jamu and Piedrahita [28] developed simulation models for organic matter and nitrogen in integrated aquaculture systems. Li and Yakupitiyage developed a dynamic model to explain food nutrient dynamics in a semi-intensive aquaculture pond and to determine food nutrient requirements for supplementary feeds for Nile tilapia. The model links food nutrient production with elementary nutrient dynamics and fish growth by including four sectors: food nutrients, fish growth, elementary nutrients, and dissolved oxygen.

A mathematical model was also developed by [30] to predict the effects of wind speed, light, $\mathrm{pH}$, Temperature, dissolved carbon dioxide and chemical oxygen demand (COD) on Dissolved Oxygen (DO) in fish ponds. Elena, et al [31] and Kochba, et al [32] showed that simulation was useful for investigating the production, transfer, and loss of inorganic nitrogen in pond systems. Jamu and Piedrahita [33] developed a model for fishpond organic matter and nitrogen dynamics which can be employed in aquaculture pond systems. Elena, et al [31] simulated the discharge of wastewater heat from a RAS facility to determine optimum greenhouse size. In [34], Singh, et al compared a continuous-time simulation language designed for solving timedependent, nonlinear differential equations with analytical solutions of the unsteady-state massbalance equations for the transfer and removal of ammonia; they concluded that simulation is a powerful tool for describing the dynamic behavior of ammonia concentration. A general discussion of the use of models in aquaculture science was also presented by [25].

Munro, et al [5] reviewed some dynamic models specific to aquaculture management and regulations. A summary of their reviewed models and an update are presented on Table 1.

\section{CONCLUSION}

The reviewed models are important and useful in maximizing aquacultural production though each of the aforementioned models was found to addressed a specific problem that pertains to a species, production systems and locality. For instance, the FIS-C addresses Salmon fish waste load, and does not predict the extant condition of the system. The TFST is mainly an economic tool; it does not incorporate natural productivity or water quality of the pond. FARM model assesses coastal and shellfish aquaculture. The PWAP model expresses water budget for fish ponds. The RDSS model was designed specifically for a raceway system. The AQUAFARM model, which can be validated and used for African indigenous species is a design and management planning of aquacultural systems.

There is none among the reviewed model that is specifically designed for African indegineous species and its environment with respect to (1) predicting the effect of different management operations on fish yield, (2) predict general pond dynamics and analyze complex relationships in production ecosystems; identify cause and suggest remedial actions for impaired systems; predict feed wastage and economic viability of the production system based on cost of feed and fingerlings used in the system; and track the fate of many water quality parameters which are not readily measured. Hence, none of the reviewed models can be used as it is, to predict the environmental condition, so as to determine point of diminishing returns and optimize yield in an economical way. However, the theoretical frame work of the Aquafarm can be adopted to develop a simulation model for African catfish. The result of reviewed literature suggest a serious need to research and develop holistic models that can predict the effects of environment on African indigenous fish species and their management options for ailing systems. The model should also be able to independently replicate different production systems with different management regimes. This will saves time and cost expended on real-world research experiments. and also help stake holders (farmers, researchers and managers) to optimize aquacultural production system and reduced cost incurred in fish production.

\section{REFERENCES}

\section{Reference}

[1] Cuenco, M. L., Aquaculture Systems Modeling: An introduction with emphasis on warmwater aquaculture, Manila, Philippines: International Center for Living Aquatic Resources Management. 1989.

[2] Wurts, W.A. and Wynne, F., Sustainable channel catfish farming: low management production 
through modified stocking and feeding practices, World Aquac. 26(3), pp54-59, 1995.

[3] Tucker, C.S., Off-flavor problems in aquaculture. Critical Reviews in Fisheries Science, 8(1), pp.1-44, 2000.

[4] Leung, P. and El-Gayar, O.F., The role of modeling in the managing and planning of sustainable aquaculture. In: Bardach, J.E. ed. Sustainable Aquaculture. John Wiley \& sons, Canada, pp 251, 1997.

[5] Munro, L.I., Falconer, L., Telfer, T.C and Ross L.G., Review of Environmental Models in Sustaining Ethical Aquaculture Trade (SEAT). SEAT Deliverable Ref: D 4.1, 2000.

[6] Hargreaves, J.A. and Tomasso, J.R., Environmental Biology. In C.S. Tucker and J.A. Hargreaves, eds. Biology and Culture of Channel Catfish. Developments in Aquaculture and Fisheries Science 34. Elsevier B.V. Netherlands. pp.36-68, 2004.

[7] Piedrahita, R., Aquaculture Systems Engineering. American Society of Aqricultural Engineers, St. Joseph, MI, 1991.

[8] Cole, B.A. and Boyd, C.E., Feeding rate, water quality, and channel catfish production in ponds. Progressive Fish-Culturist, 81, pp.25-29, 1986.

[9] Tucker, C.S. and Hargreaves, J.A., Pond Water Quality. In C.S. Tucker and J.A. Hargreaves, eds. Biology and Culture of Channel Catfish. Developments in Aquaculture and Fisheries Science -34. Elsevier B.V. Netherlands. pp.215- 278, 2004.

[10] Boyd, C.E., Water Quality in Ponds for Aquaculture. Auburn, AL: Auburn University/Alabama Agricultural Experiment Station, 1990.

[11] Plaganyi, E.E., Models for an ecosystem approach to fisheries. FAO Fisheries Technical Paper. No. 477. Rome, FA0.108p, 2007.

[12] Cuenco, M. L., A model of fish bioenergetics and growth at the organismal and population levels in laboratory and pond environments, Ph.D dissertation. Texas A and M University Texas, 1982.

[13] Allen, P. G., Botsford, L. W., Schuur, A. M. \& Johnston, W. E., Bioeconomics of Aquaculture, Elsevier Scientific Publishers, Amsterdam, 1984.

[14] Nirmalakhandan, N., Modeling Tools for Environmental Engineers and Scientists. CRC Press LLC, Florida. 328pp, 2002.

[15] Mulligan, M. \& Wainwright, J., Modelling and model building. In: Wainwright, J. \& Mulligan, M. eds. Environmental Modelling: Finding simplicity in complexity. John Wiley \& Sons, West Sussex. 430pp; 2004.

[16] Smith, J. and Smith, P., Environmental Modelling: An introduction. Oxford University Press, New York. USA, 2007.
[17] Beveridge, M.C.M, Cage Aquaculture. 3rd edition. Blackwell Publishing Ltd, Oxford. 368pp, 2004.

[18] McDonald, M.E., Tikkanen, C.A., Axler, R.P., Larsen, C.P. and Host, G., Fish Simulation Culture Model (FISC): A Bioenergetics Based Model for Aquacultural Wasteload Application. Aquacultural Engineering, 15(4), pp.243-259, 1996

[19] De Graaf, G. J., Johan, P. J. and Verreth, A. J., Simulation of Nile tilapia (Orechromis niloticus Niloticus L.) culture in ponds, through individual based modeling, using a population dynamic approach. Aquaculture Research, 36(5), pp. 455-471, 2005.

[20] Ferreira, J.G., Hawkins, A.J.S. and Bricker, S.B., Management of productivity, environmental effects and profitability of shellfish aquaculture - the Farm Aquaculture Resource Management (FARM) model. Aquaculture, 264, p.160-174, 2007.

[21] Kam, S.P. and Hoanh, C.T., Modelling Pond-Water Availability for Fish Culture. [Online] Available at http://www.mssanz.org.au/MODSIM07/papers/23 s31/ModellingPond s31_Kam.pdf [Accessed 18 November 2010], 2008.

[22] Ernst, D. H., Bolte, J. P. and Nath, S. S., AquaFarm: simulation and decision support for aquaculture facility design and management planning. Aquacultural Engineering, Volume 23, p. 121-179, 2000.

[23] Wang, Y.-H., Turton, R., Semmens, K. and Borisova, T., Raceway design and simulation system (RDSS): An event-based program to simulate the day-to-day operations of multiple-tank raceways. Aquacultural Engineering, Volume 39, p. 59-71, 2008.

[24] Yi, Y., A bioenergetics growth model for Nile tilapia (Oreochromis niloticus) based on limiting nutrients and fish standing crop in fertilized ponds. Aquacultural Engineering, Volume 18, pp. 157-173, 1998.

[25] High Performance Systems, Inc., STELLA II Software Program. Hanover, New Hampshire, 1990.

[26] Ursin, E., A mathematical model of some aspects of fish growth, respiration, and mortality. Journal of the Fisheries Research Board of Canada, 24, pp.2355453, 1967.

[27] Svirezhev, Y.M., Krysanova, V.P. and Voinov, A.A., Mathematical Modelling of a Fish Pond Ecosystem. Ecological Modelling, 21, pp.315- 337, 1984.

[28] Jamu, D.M. and Piedrahita, R.H., An organic matter and nitrogen dynamics model for the ecological analysis of integrated aquaculture/agriculture systems: I. Model development and calibration. Environmental Modelling and Software, 17, p.571582, 2002. 
[29] Li, L. and Yakupitiyage, A., A model for food nutrient dynamics of semi-intensive pond fish culture. Aquacultural Engineering, 27, pp.9-38, 2003.

[30] Mwegoha, W.J.S., Kaseva, M.E. and Sabai, S.M.M., Mathematical modelling of dissolved oxygen in fish ponds. African Journal of Environmental Science and Technology, 4(9), pp.625- 638, 2010.

[31] Ellner, S., Neori, A., Krom, M.D., Tsai, K. and Easterling, M.R. Simulation model of re-circulating mariculture with seaweed bio-filter: development and experimental tests of the model. Aquaculture, 143, p.167-184, 1996.

[32] Kochba, M., Diab, S. and Avnimelech, Y., Modelling of nitrogen transformation in intensive aerated fish ponds. Aquaculture, 120, p.95-104, 1994.

[33] Jamu, D.M. and Piedrahita, R.H., Aquaculture Pond Modelling for the Analysis of Integrated Aquaculture/Agriculture Systems: Fishpond Organic Matter and Nitrogen Dynamics. Interim Work Plan, DAST Study 5. Data Analysis and Synthesis. Fourteenth annual technical report, 1997.

[34] Singh, S., Marsh, L.S., Vaughan, D.H. and Libey, G.S., A computer simulation model to optimize greenhouse size for an integrated (fish production, hydroponics) system. Transactions of the ASAE (American Society of Agricultural Engineers), 39, p.2241-2248, 1996.

[35] Weatherley, L.R., Hill, R.G. and Macmillan, K.J., Process modelling of an intensive aquaculture system. Aquacultural Engineering, 12, p.215-230, 1993.

[36] Cromey, C.J., Nickell, T.D. and Black, K.D., DEPOMOD - modelling the deposition and biological effects of waste solids from marine cage farms. Aquaculture, 214, pp.211- 239, 2002.
[37] SAMS, Ecosystem Approach for Sustainable Aquaculture (ECASA). [Internet] Available from <www.ecasa.org.uk> [accessed 5th May 2010], 2004.

[38] Culberson, S.T., and Piedrahita, R.H., Aquaculture pod ecosystem modelling: temperature and dissolved oxygen prediction- mechanism and application. Ecological modelling, 89, pp231-258, 1996.

[39] Dudley, R.W., Panchang, V.G. and Newell, C.R., Application of a comprehensive modelling strategy for the management of net-pen aquaculture waste transport. Aquaculture, 187, pp319-349, 2000.

[40] Schaffner, M., Bader, H.P. and Scheidegger, R., Modelling the contribution of point sources and nonpoint sources to Thachin River water pollution. Science of the Total Environment, 407, pp49024915, 2009.

[41] Spruill, C.A., Workman, S.R., Taraba, J.L., Simulation of daily and monthly stream discharge from small watersheds using the SWAT model. American society of Agricultural Engineers, 43, pp1431-1439, 2000.

[42] EcoWin 2000 Website.[Internet]. Available from $<$ http://www.ecowin2000.com> [accessed 15th May 2010]

[43] Hansen, P.K., Ervik, A., Schaanning, M., Johannessen, P., Aure, J., Jahnsen, T. and Stigebrandt, A., Regulating the local environmental impact of intensive, marine fish farming II. The monitoring programme of the MOM system (Modelling-Ongrowing fish farms Monitoring). Aquaculture, 194: 75-92, 2001.

Table 1. A Summary of reviewed Aquaculture Production Models

\begin{tabular}{|c|c|c|c|c|}
\hline Model & Type & Package & Description & Reference \\
\hline DEPOMOD & $\begin{array}{l}\text { Waste Dispersion } \\
\text { model developed for } \\
\text { Atlantic Salmon } \\
\text { Aquaculture farms }\end{array}$ & $\begin{array}{l}\text { Visual Basic } \\
\text { (Computer } \\
\text { Language) }\end{array}$ & $\begin{array}{l}\text { Relevance in regulation of coastal aquaculture. } \\
\text { is used at the pre-development stage for fish } \\
\text { farm sites to estimate the maximum production } \\
\text { biomass which can be supported by local } \\
\text { environmental services }\end{array}$ & [36] \\
\hline COD-MOD & $\begin{array}{l}\text { Waste Dispersion model } \\
\text { derived from DEPOMOD } \\
\text { but for use for Atlantic cod } \\
\text { grown in marine cages }\end{array}$ & $\begin{array}{l}\text { Visual Basic } \\
\text { (Computer } \\
\text { Language) }\end{array}$ & $\begin{array}{l}\text { It seems to work well when validated using field } \\
\text { data, as little is still known regarding the } \\
\text { environmental aspects of cod grown in marine } \\
\text { cages, considerable amounts of data are } \\
\text { required for its operation rather than the general } \\
\text { derived assumptions used for salmonids. }\end{array}$ & [36] \\
\hline MERAMOD & $\begin{array}{l}\text { Waste Dispersion model } \\
\text { developed from the } \\
\text { DEPOMOD model but } \\
\text { adapted for sea bream in } \\
\text { the Mediterranean }\end{array}$ & $\begin{array}{l}\text { Borland } \\
\text { Delphi } 7\end{array}$ & $\begin{array}{l}\text { Takes into account total solids and other } \\
\text { particulates as well as accounting for } \\
\text { macrobenthic indicator species, and estimates } \\
\text { for the effects by consumption of released } \\
\text { wastes by indigenous fish species attracted to } \\
\text { the culture cages }\end{array}$ & [37] \\
\hline
\end{tabular}




\begin{tabular}{|c|c|c|c|c|}
\hline Model & Type & Package & Description & Reference \\
\hline $\begin{array}{l}\text { FARM (FarmAquaculture } \\
\text { Resources Management) }\end{array}$ & $\begin{array}{l}\text { Resource management } \\
\text { based on shellfish } \\
\text { cultivation. }\end{array}$ & STELLA & $\begin{array}{l}\text { Developed in order to allow an aquaculturist to } \\
\text { determine the maximum shellfish density that } \\
\text { would provide a sustainable carrying capacity to } \\
\text { the surrounding area. It involves the integration } \\
\text { of a number of models including; growth models } \\
\text { for both finfish and shellfish, production models, } \\
\text { economic models and nutrient and } \\
\text { eutrophication models. Currently undergoing } \\
\text { more developments to allow it to model for other } \\
\text { forms of culture such as seaweeds and fish } \\
\text { cages. }\end{array}$ & [20] \\
\hline $\begin{array}{l}\text { APEM (Aquaculture Pond } \\
\text { Ecosystem Management) }\end{array}$ & $\begin{array}{l}\text { Environmental ecosystem } \\
\text { dynamics developed in } \\
\text { order to provide a simpler } \\
\text { more general, user friendly, } \\
\text { method for modelling pond } \\
\text { systems, enabling } \\
\text { application to a number of } \\
\text { ponds types. }\end{array}$ & STELLA & $\begin{array}{l}\text { The mode looks at the biological, physical and } \\
\text { chemical aspects of the pond but simplifies the } \\
\text { processing. It produced accounts for } \\
\text { Temperature and thermal energy dynamics, } \\
\text { simulating the vertical heat transfer within the } \\
\text { pond as well as the Dissolved Oxygen } \\
\text { dynamics, simulating plankton photorespiration } \\
\text { and sediment and water column respiration. }\end{array}$ & [38] \\
\hline $\begin{array}{l}\text { IAAS (Integrated } \\
\text { Aquaculture/Agriculture } \\
\text { System) }\end{array}$ & $\begin{array}{l}\text { Evironmental ecosystem } \\
\text { dynamics }\end{array}$ & STELLA & $\begin{array}{l}\text { The model simulates fish and crop production, } \\
\text { organic matter, phytoplankton, dissolved oxygen } \\
\text { and the nitrogen dynamics in the system. }\end{array}$ & [28] \\
\hline $\begin{array}{l}\text { AWATS (Aquaculture } \\
\text { Waste Transport } \\
\text { Simulator) }\end{array}$ & $\begin{array}{l}\text { Waste transport model } \\
\text { developed using a series of } \\
\text { existing validated models }\end{array}$ & Various & $\begin{array}{l}\text { The overall model simulates the transport of } \\
\text { wastes from finfish net pen aquaculture systems } \\
\text { and is intended to be used for regulatory } \\
\text { purposes. }\end{array}$ & [39] \\
\hline $\begin{array}{l}\text { MMFA (Mathematical } \\
\text { Material Flow Analysis) }\end{array}$ & $\begin{array}{l}\text { Material flow model } \\
\text { developed for use in } \\
\text { pollution monitoring and } \\
\text { material flows through a } \\
\text { system. }\end{array}$ & Spreadsheet & $\begin{array}{l}\text { Used to quantify the nutrient loading and } \\
\text { consequent carrying capacity of the river, by } \\
\text { taking into account both agriculture and } \\
\text { aquaculture activities simulating the loading } \\
\text { from each to determine the largest polluter in } \\
\text { terms of nitrogen and phosphorus. It is desirable } \\
\text { to use it in combination or to complement a } \\
\text { system dynamics model to provide a wider } \\
\text { understanding of the workings and carrying } \\
\text { capacity for any aquatic system }\end{array}$ & {$[40]$} \\
\hline $\begin{array}{l}\text { SWAT (Soil and Water } \\
\text { Assessment Tool) }\end{array}$ & $\begin{array}{l}\text { Water quality/ Groundwater } \\
\text { modelling. } \\
\text { A long-term assessment } \\
\text { tool for simulations of } \\
\text { watershed dynamics }\end{array}$ & $\begin{array}{l}\text { Visual Basic } \\
\text { (Computer } \\
\text { Language) }\end{array}$ & $\begin{array}{l}\text { SWAT was originally developed for use with } \\
\text { nutrient loading of water sources from land } \\
\text { based activities and has been used for } \\
\text { estimating nutrient loads to local watersheds in } \\
\text { relation to salmon farming. }\end{array}$ & {$[41]$} \\
\hline EcoWin2000 & Ecosystem model & $\begin{array}{l}\text { Ecowin2000 } \\
\text { software }\end{array}$ & $\begin{array}{l}\text { It is used for modelling of aquatic systems } \\
\text { through an object-oriented approach in which a } \\
\text { 'series of self-contained objects' are coordinated } \\
\text { by a shell module which communicates and } \\
\text { transfers information between the individual } \\
\text { objects. mostly used for analysis of large } \\
\text { coastal systems by breaking the extended areas } \\
\text { into boxes which are dealt with individually. }\end{array}$ & {$[42]$} \\
\hline $\begin{array}{l}\text { MOM (Modelling- } \\
\text { Ongrowing fish farm- } \\
\text { Monitoring) }\end{array}$ & Environmental impact & Various & $\begin{array}{l}\text { A Norwegian based model to simulate the } \\
\text { carrying capacity of a site for Aquaculture. The } \\
\text { model has now been developed to include } \\
\text { shellfish farming. }\end{array}$ & {$[43]$} \\
\hline KK3D & $\begin{array}{l}\text { deposition a waste } \\
\text { deposition model for use in } \\
\text { mariculture, which can be } \\
\text { applied to both local scale } \\
\text { and water body scale }\end{array}$ & $\mathrm{C}++$ & $\begin{array}{l}\text { It uses input data for feed composition, } \\
\text { geometry of net-pens, variation in emissions } \\
\text { over a given time scale, faecal pellet solubility, } \\
\text { current velocity, settling rate of faecal pellets } \\
\text { and realistic bathymetry data. }\end{array}$ & {$[37]$} \\
\hline
\end{tabular}




\begin{tabular}{|c|c|c|c|c|}
\hline Model & Type & Package & Description & Reference \\
\hline $\begin{array}{l}\text { Fish Simulation Culture } \\
\text { Model (FIS-C) }\end{array}$ & $\begin{array}{l}\text { bioenergetics based model } \\
\text { for aquacultural waste load } \\
\text { application }\end{array}$ & & $\begin{array}{l}\text { It can provide rapid, short and long term } \\
\text { estimates of consumption and sediment solids } \\
\text { without the necessity of performing multiple, } \\
\text { user intensive simulations. }\end{array}$ & [18] \\
\hline $\begin{array}{l}\text { Tilapia Farming Support } \\
\text { Tool (TFST) }\end{array}$ & $\begin{array}{l}\text { an economic tool developed } \\
\text { by Nefisco and Xi }\end{array}$ & & $\begin{array}{l}\text { It assists in the formulation of the most optimal } \\
\text { Tilapia farming systems taking into } \\
\text { consideration the local economy and consumer } \\
\text { preferences }\end{array}$ & [19] \\
\hline $\begin{array}{l}\text { Pond-Water Availability } \\
\text { Period (PWAP) model }\end{array}$ & $\begin{array}{l}\text { expresses water budget for } \\
\text { fish ponds based on } \\
\text { prevailing climatic and } \\
\text { hydrological conditions. }\end{array}$ & & $\begin{array}{l}\text { Initially developed for point-based evaluation, } \\
\text { the model is being further programmed for } \\
\text { evaluation in a GIS environment to generate } \\
\text { gridded maps of pond-water availability. }\end{array}$ & [21] \\
\hline $\begin{array}{l}\text { Raceway design and } \\
\text { simulation system (RDSS) }\end{array}$ & $\begin{array}{l}\text { An event-based program } \\
\text { that simulate the day-to- } \\
\text { day operations of multiple- } \\
\text { tank raceways. }\end{array}$ & Visual Basic. & $\begin{array}{l}\text { The software allows users to manage their } \\
\text { raceways more efficiently by providing a tool to } \\
\text { simulate the operation of an existing raceway or } \\
\text { to predict conditions in a raceway under a wide } \\
\text { variety of operating conditions. }\end{array}$ & [23] \\
\hline $\begin{array}{l}\text { bioenergetics growth } \\
\text { model for Nile tilapia } \\
\text { (Oreochromis niloticus) }\end{array}$ & $\begin{array}{l}\text { based on limiting nutrients } \\
\text { and fish standing crop in } \\
\text { fertilized ponds }\end{array}$ & STELLA® II & $\begin{array}{l}\text { Model results improve understanding of } \\
\text { aquaculture pond ecosystems and is useful for } \\
\text { the optimization of fertilizer utilization }\end{array}$ & [24] \\
\hline
\end{tabular}

